\title{
BIOREFINERIES - NEW GREEN STRATEGY FOR DEVELOPMENT OF SMART AND INNOVATIVE INDUSTRY
}

\author{
Grażyna A. PŁAZA, Dorota WANDZICH \\ Silesian University of Technology
}

\begin{abstract}
:
Ecological engineering or ecotechnology is defined as the design of sustainable production that integrate human society with the natural environment for the benefit of both. In order to reach the goal of sustainability therefore important that bioproduct production systems are converted from to natural cycle oriented. In natural cycles there are not waste, but products are generated at different stages of the cycle. The ecotechnology creates a sustainable bioeconomy using biomass in a smart and efficient way. The biorefining sector, which uses smart, innovative and efficient technologies to convert biomass feedstocks into a range of bio-based products including fuels, chemicals, power, food, and renewable oils, currently presents the innovative and efficient bio-based production can revitalize existing industries.

The paper presents the concept of biorefinery as the ecotechnological approach for creating a sustainable bioeconomy using biomass in a smart and efficient way.
\end{abstract}

Key words: ecological engineering, biorefinery, biomass, bioprocess, industrial metabolism, renewableand sustainable resources

\section{INTRODUCTION}

Biorefineries are at the centre of the bioeconomy and contribute to the principles of a "zero waste» society. The concept of biorefineries is analogous to that of petrochemical refinery processes, which produce a wide range of products and fuels from fossil resources (Figure 1). Industrial biorefineries have been identified as the most promising routes to the creation of a bio-based economy $[8,14]$.

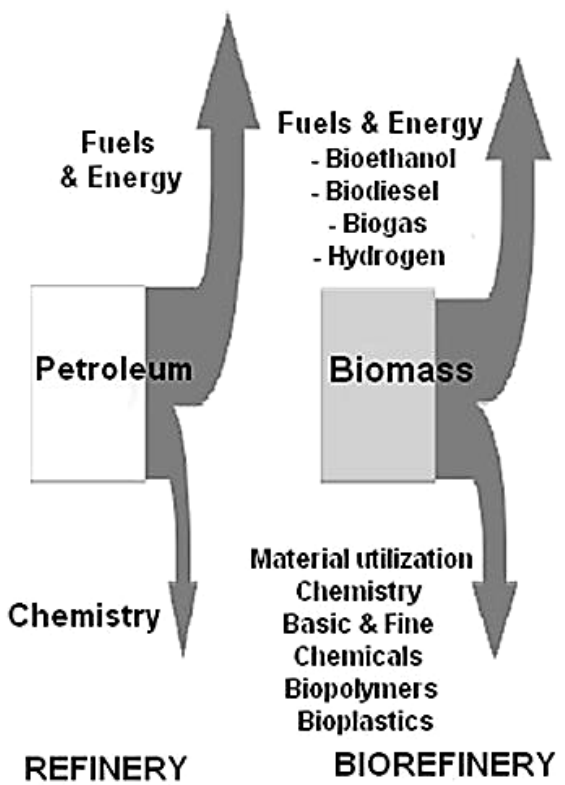

Fig. 1 Comparison of the basic-principles of the petroleum refinery and the biorefinery

Source: based on [6].
These systems can be improved through better utilization of residues and optimization of total added value creation; new biorefineries can be enhanced by applying the lessons learned from existing facilities to comparable situations. Biorefineries aim to produce multiple bio-based products and fuels instead using biomass as a carbon source and bio-based processes. The term "bio-based products" refers to three different product categories: biofuels (e.g. biodiesel and bioethanol), bio-energy (heat and power) and bio-based chemicals and materials (e.g. succinic acid and polylactic acid). They are produced by a biorefinery that integrates the biomass conversion processes. The biorefinery concept can be integrated in a wide range of environments, ranging from small-scale plants using agricultural residues in remote rural areas to large plants using waste from surrounding industries and municipalities in a symbiotic manner. The document entitled "European Biorefinery 2030 Vision" provides the information and tools to enable policy makers to build a framework for the development of a sustainable knowledge-based European bioeconomy, with a network of biorefineries playing an essential role.

Biorefineries could potentially use complex processing strategies to efficiently produce adverse and flexible mix of conventional products, fuels, electricity, heat, chemicals, and material products from all available, environmentally appropriate biomass feedstocks. The biorefinaries are characterized by [3]:

- develop of specific separation and fractionation technologies for high-throughput systems that produce value-added products and no waste streams,

- generic solutions that apply across multiple feedstocks while simultaneously achieving a zero-waste 
G. A. PŁAZA, D. WANDZICH - Biorefineries - new green strategy for development of smart and innovative industry

production system with either direct use or recycling of all components.

Various biorefinery systems will emerge commercially in the future, taking advantage of flexible technology, helping the concept of a biorefinery to process locally available biomass to its fullest in an integrated fuel chemicalmaterial-power cycle, improving cost-efficiency, the life quality of the local population and lowering the environmental impact governed by the three dimensions of sustainability: environmental protection, social progress and economic development [15] (Fig. 2).

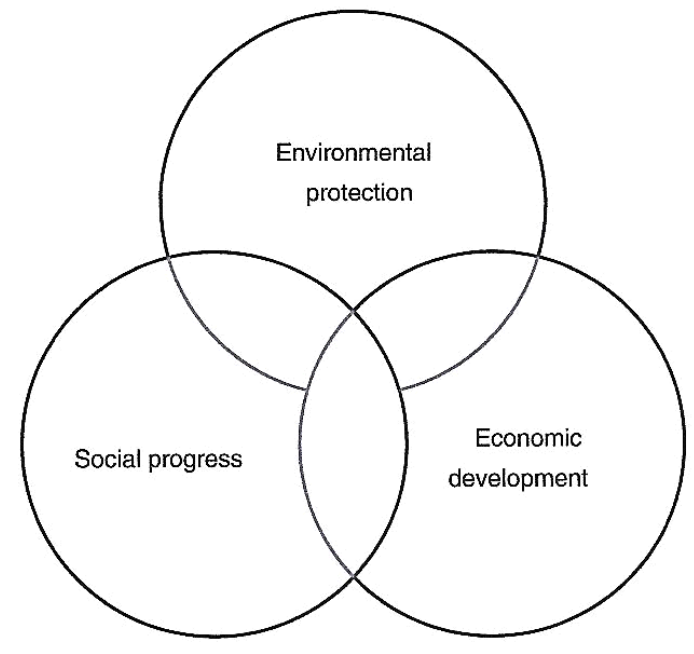

Fig. 2 Three dimensions of sustainability: environmental protection, social progress and economic development Source: based on [15].

\section{DEFINITIONS OF BIOREFINERY}

Several definitions and explanations of biorefinery have been developed over the last few years according to the context, but the core concept embedded in all definitions is the conversion of biomass into several product streams (materials, chemicals, energy, food and feed) and the integration of various technologies and processes in the most sustainable way.

In Table 1 some examples of biorefinery definitions are presented. Among the several definitions of biorefinery/ biorefining, the most widely used and accomplished by the International Energy Agency (IEA) "Biorefinery Task 42" is: "Biorefining is the sustainable processing of biomass into a spectrum of marketable products and energy" [9]. In other words, biomass is sustainably used as a resource for production of among others heat, power, fuels, chemicals and materials [6]. The term biorefinery was redefined during the realization of the project "Biorefinery Euro view" as follows: "Biorefiniers are described as integrated biobased industries using a variety of technologies to make products such as chemicals, biofuels, food and feed ingredients, biomaterials, fibers, and heat and power, aiming at maximizing the added value along the three pillares of sustainability (environment, economy and society) [7].

The biorefinery is an industrial facility (or network of facilities) that cover an extensive range of combined technologies aiming to full sustainable transformation of biomass into their building blocks with the concomitant production of biofuels, energy, chemicals and materials, preferably of added-value [5]. The raw materials that can be used as feedstock for a biorefinery are, for example crops and residues, lignocellulosic material, municipal solid waste (MSW) and algae. They are provided by four different sectors: agriculture, forestry industries and aquaculture. Biorefineries apply a wide range of technologies to separate the biomass inputs into their building blocks, such as hydrogen, carbohydrates and proteins, which then are converted into value added products [5]. The concept of biorefinery in much more than a simple definition, it is a valuable strategy to focus on the green economy era that will be played a fundamental role in the near future [7].

\section{CONCEPT OF BIOREFINERIES}

The biorefinery concept embraces a wide range of technologies able to separate biomass resources (wood, grasses, corn) into their building blocks (carbohydrates, proteins, triglycerides) which can be converted to value added products, biofuels and chemicals. A biorefinery is a facility (or network of facilities) that integrates biomass conversion processes and equipment to produce transportation biofuels, power, and chemicals from biomass.

Table 1

Examples of biorefinery definitions

\begin{tabular}{ll}
\hline Source & Definition \\
\hline $\begin{array}{l}\text { NREL } \\
\text { (en.wikipedia.org/wiki/Biorefinery) }\end{array}$ & $\begin{array}{l}\text { A biorefinery is a facility that integrates biomass conversion processes } \\
\text { and equipment to produce fuels, power, and value-added } \\
\text { chemicals from biomass. The biorefinery concept is analogous to today's } \\
\text { petroleum refinery, which produce multiple fuels and products from pe- } \\
\text { troleum. } \\
\text { Cluster of biobased industriesproducing chemicals, fuels, power, products, } \\
\text { and materials. }\end{array}$ \\
www.biorenew.iastate.edu/resources/glossary.php & $\begin{array}{l}\text { A biorefinery is an overall conceptof a processing plant where biomass } \\
\text { feedstocks are converted and extracted into a spectrum of valuable prod- } \\
\text { uS-DOE }\end{array}$ \\
$\begin{array}{l}\text { ucts } \\
\text { NL }\end{array}$ & $\begin{array}{l}\text { The separation of biomass into distinct components which can be individu- } \\
\text { ally brought to the market either directly after separation or after further } \\
\text { (biological, thermochemical/chemical) treatment(s) } \\
\text { Addition of Pure Plant Oil into traditional oil refineries }\end{array}$ \\
\hline
\end{tabular}


Table 2

Examples of the processes within the biorefinery concept

\begin{tabular}{|c|c|c|c|}
\hline \multicolumn{4}{|c|}{ Types of the processes } \\
\hline Mechanical & Biochemical & Chemical/physical & Termochemical \\
\hline Pressing & Anaerobic digestion & Hydrolysis & Pyrolysis \\
Milling & Aerobic \& anaerobic transformation & Transestrification\& esterification & Combustion \\
Sieving & Enzymatic conversion & Hydrogenation & Oxidation \\
Pelletization & & Methanization & Supercritical \\
Mixing & & Catalysis & Direct combustion \\
Extrusion & & Distillation/Evaporation & \\
Grinding & & Pulping & \\
& & Membrane & \\
& & Polymerization & \\
& & Flocculation/Coagulation & \\
\hline
\end{tabular}

The biorefinery concept is analogous to today's petroleum refineries, which produce multiple fuels and products from petroleum as presented in Figure 1.

The principle components of the biorefinery design are: biomass and four basic groups of different technological processes (mechanical, biochemical, chemical, and thermochemical) which complement each other very well. In Table 2 the kinds of the technological processes are listed. In order to separate the biomass input to the biorefinery into its constituting elements and convert by the 4 technological processes and their different combinations into valuable products can be used. Biological processes (bioprocesses) use biological organisms (e.g., microorganisms, enzymes) and are used as part of the conversion processes in a biorefinery along with other low environmental impact methods such as chemical and thermo-chemical. The interconnections of different disciplines such as chemistry, chemical engineering, biotechnology and biology together with techno-economic and sustainability assessment, are crucial for the development of a successful fully integrated biorefinery.

The term "feedstock" refers to raw materials used in biorefinery [10]. The biomass is synthesized via the photosynthetic process that converts atmospheric carbon dioxide and water into sugars. Plants use the sugar to synthesize the complex materials that are generically named biomass. An important stage in biorefinery system is the provision of a renewable, consistent and regular supply of feedstock. Initial processing may be required to increase its energy density to reduce transport, handling and storage costs [15]. Renewable carbon-based raw materials for biorefinery are generally provided from four different sectors: 1 . agriculture (dedicated crops and residues), 2. forestry, 3. industries (process residues and leftovers) and households (municipal solid waste and wastewaters), 4. aquaculture (algae and seaweeds) [7].

Biomass includes a great variety of different and often complex plant components embedded in a matrix that differs according to the origin of the biomass used. There are three biomass feedstocks: carbohydrate (starch, cellulose and hemicellulose) and lignin from lignocellulosic biomass, triglycerides (soybean, palm, rapeseed, sunflower oil) and mixed organic residues [7]. Lignocellulosic feedstocks can be obtained through the production of dedicated crops such as miscanthus or short rotation woody crops such as willow or poplar. Agricultural residues such as rice or wheat straw and paper pulp from the paper industry are other examples of sources of lignocellulosic material. Biomass feedstockscan be also classified into two main categories: (1) dedicated feedstocks like sugar crops, i.e., sugarcane; starch crops, i.e. sweet sorghum; lignocellulosic crops, i.e., switchgrass; oil crops, i.e., soya, jatropha; grass crops, i.e., grass sillage; marine crops, i.e. seaweed, and (2) residues/ by products (oil-based residues, i.e., waste cooking oil, tallow; lignocellulosic residue, i.e., rice husks, tomato pomace, logging residue; industrial organic residues, i.e., manure; domestic organic residue).

The basic of technological process in biorefinery is depolymerizing and deoxygenating the biomass components. In order to convert biomass feedstock into valuable products within a biorefinery approach, several technological processes are jointly applied. The Figure $3 a$ and $3 b$ presents the product's life cycle in the biorefinery.

a)

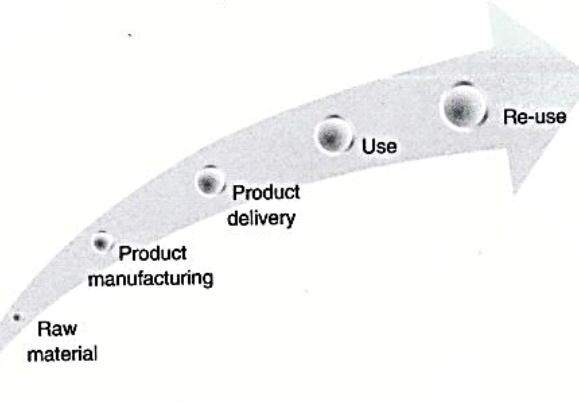

b)

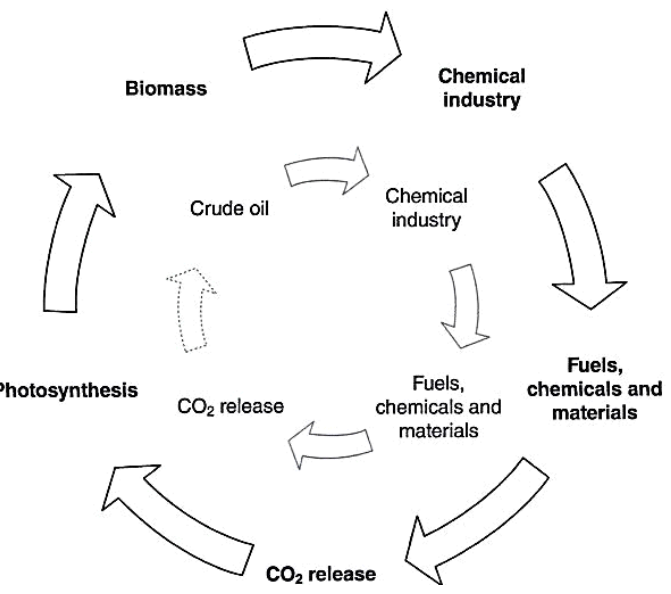

Fig. 3 The product's life cycle in the biorefinery Source: based on [6]. 
The products of biorefinery systems can be grouped in two broad categories: material products and energy products [19]. Energy products are those products which providing electricity, heat or transportation service. The most important energy products which can be produced in biorefineries are: gaseous biofuels (biogas, syngas, hydrogen, biomethane), solid biofuels (pellets, lignin, charcoal), liquid biofuels for transportation (bioethanol, biodiesel, FT-fuels, bio-oil). The most important chemical and material products are: chemicals (fine chemicals, building blocks, bulk chemicals), organic acids (succinic, lactic, itaconic and other sugar derivatives), polymers and resins (starch-based plastics, phenol resins, furan resins), biomaterials (wood panels, pulp, paper, cellulose), food and animal feed, fertilizers.

Biorefineries can be subdivided via over simplification into biorefineries of I, II and III generation according to the feedstock and process used, as well as product targeted (chemicals or energy) [4, 10]. Phase I biorefineries focus on the conversion of one feedstock, using one process and targeting one product. A biodiesel production plant would be a good example of a phase I biorefinery: rapeseed or sunflower is used for oil extraction, which is subsequently transesterified to produce fatty acid methyl esters or biodiesel using methanol and a catalyst $[2,17]$. Phase II biorefineries differ from phase I biorefineries by the number of outputs they can produce. A typical example of a phase II biorefinery is the production of starch, ethanol and lactic acid together with high fructose syrup, corn syrup, corn oil and corn meal from corn wet mil operations. Phase III biorefineries allow for a wider range of technologies, to be combined (e.g., supercritical $\mathrm{CO}_{2}$ extraction followed by biological transformation), in comparison to phase I and II biorefineries. They also allow for a higher number of valorized outputs since several constituents of the feedstock used can be treated separately. Biorefineries falling into that category can also be called "product-driven biorefineries". They generate two or more bio-based products and the residue is used to produce energy (either fuel, power and/or heat) [1]. Examples of phase III biorefineries include whole crop biorefineries which make use of several agricultural by-products originating from the same crop. Phase III biorefineries are typically the ones targeting the production of chemicals and fuels. Sub-categories also exist according to the type of technology used (thermo-chemical or biochemical biorefineries).

There is no common understanding concerning the categorization of the biorefinery concepts. Van Ree and Annevelink [20] distinguish seven types of biorefinieries: conventional biorefinery, green biorefinery, whole-crop biorefinery, lignocellulose feedstock biorefinery, twoplatform biorefinery, thermo-chemical biorefinery, and marine biorefinery. In addition, Kamm et al. [11] consider four different biorefinery systems: 1 . lignocellulosic feedstock biorefinery (use of "nature-dry" raw materials, such as waste), 2. whole-crop biorefinery (use cereals, maize), 3 . green biorefinery (use of "nature-wet" biomass like grass), and 4. two-platform concept (inclusion of sugar and syngas platform).

Another classification has now been adopted by the IEA Bioenergy Task in is based on the four cornerstones of the biorefinery concept: feedstock used (i.e., dedicated crop, process or agricultural residue, algae), platform products obtained (i.e., C5 sugars, pyrolysis oil or syngas), final products obtained (energy or chemicals) and process used [4].
This classification has the advantage of accounting for the need to apply a given technology to different feedstocks and will therefore include biorefineries developed in the future. Biorefineries is mostly designed in a generic way but should be adapted to the best technology and the best feedstock available in the geographical location chosen. Modern industries consider organic waste as important resource because of re-use, recycling or energy recovery [7]. Organic waste mainly composed by agriculture waste, yard and forestry waste, sludge, food processing waste and organic house-hold waste are available in large amounts in Europe (Fig. 4).

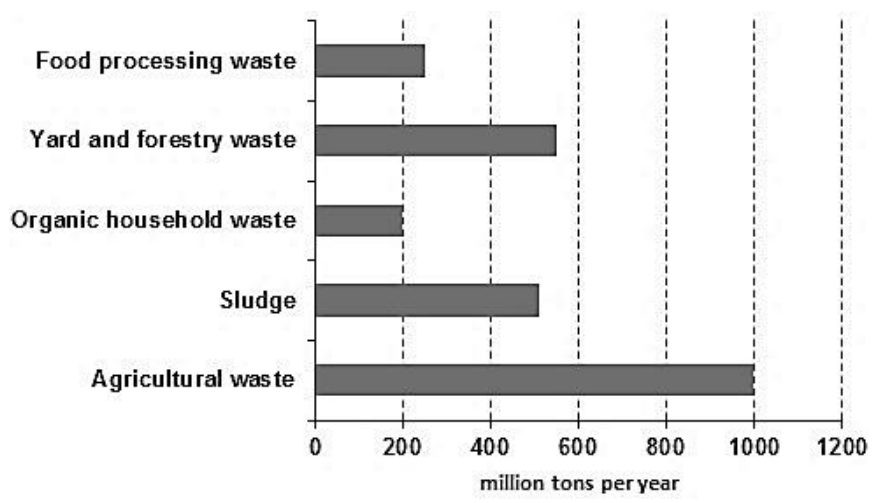

Fig. 4 Types and amounts biowaste produced in Europe Source: based on [7].

By producing multiple products, a biorefinery can take advantage of the natural complexity and differences in biomass components and intermediates and therefore maximize the value derived from the biomass feedstock. A biorefinery might, for example, produce one or several lowvolume, but high-value chemical products and a low-value, but high-volume platform chemical and/or liquid fuel; while generating power and heat for its own use, and likely enough for electricity sale. The high-value products help to meet European energy needs and $\mathrm{CO}_{2}$ emission reduction goals; whereas the power and/or heat both reduces overall production costs and greenhouse gas emissions.

\section{EUROPEN BIOREFINERIES}

The concept of biorefinery is not new, as it has been around for many years in the form of paper mills. There are two the oldest paper mills in Europe that now they are operating as biorefineries: the Borregaard biorefinery in Sarpsborg in Norway, and the Domsjo biorefinery in Ornskoldsvik in Sweden.

In Europe, there are several refineries that convert biomass into marketable products such as chemical products or biofuels. The examples are: the green biorefinery in Feldbach in Austria which produces lactic acid, amino acid, fibers, feed biogas, Bioraf Danmark in Frederiksberg in Denmark produced fibers, starch, oils, proteins, and the green biorefinery in Brensbach in Germany (Biowert GmbH) produced fibers, plastics, proteins, fertilizer, biogas [12]. The European Commission has taken an interest in biorefinery concepts to maximize the value derived from the biomass. Within the $6^{\text {th }}$ Framework Programme for Research and Technological Development two projects connected with biorefinery concepts were initiated BIOREFINIERY EUROVIEW and BIOPOL. In Horizon 2020 there are several calls connected with the biorefinery subject. The European biorefineries at commercial scale are listed in Table 3. 


\begin{tabular}{|c|c|c|}
\hline Country & Name & Company \\
\hline \multirow[t]{3}{*}{ AUSTRIA } & LenzingPul Mill & Lenzing \\
\hline & PischelsdorfBiorefinery & AGRANA \\
\hline & PölsBiorefinery & ZellstoffPöls AG \\
\hline \multirow[t]{3}{*}{ BELGIUM } & Aalst Wheat Processing Plant & Tereos Starch \& Sweeteners Europe \\
\hline & & BioWanze \\
\hline & Wanze Bioethanol Plant & \\
\hline FINLAND & UPM LappeerantaBiorefinery & UPM Biofuels \\
\hline \multirow[t]{4}{*}{ FRANCE } & Pomacle-BazancourtBiorefinery & Soliance, Chamtor, Bazancourt's Sugar Refinery, Cristanol, \\
\hline & & $\begin{array}{l}\text { Vivescia and Air Liquid (www.institut-europeen-de-la- } \\
\text { bioraffinerie.fr) }\end{array}$ \\
\hline & & Roquette \\
\hline & Lestream Starch Biorefinery & \\
\hline \multirow[t]{4}{*}{ GERMANY } & Krefeld Starch Biorefinery & Cargill \\
\hline & Schwedt Biorefinery & Verbio \\
\hline & Zeitz Bioethanol Plant & CropEnergies Bioethanol GmbH \\
\hline & ZörbigBiorefinery & Verbio \\
\hline \multirow[t]{6}{*}{ ITALY } & Caserta Levulinic Acid Plant & GFBiochemicals \\
\hline & Cassano Succinic Acid Plant & Reverdia \\
\hline & Crescentino Bioethanol Plant & Beta Renewables \\
\hline & MatricaBiorefinery & Novamont\&Versalis (www.matrica.it) \\
\hline & & eni \\
\hline & Venice Biorefinery & \\
\hline \multirow[t]{5}{*}{ NETHERLAND } & DelfzijBiomethanol Plant & BioMCN \\
\hline & Greenmills Project & Biodiesel Amsterdam, Noba, Orgaworld\&Rotie \\
\hline & & Neste Oil \\
\hline & Rotterdam Biorefinery & Cargill \\
\hline & Sas van Gent Biorefinery & \\
\hline NORWAY & SarpsborgBiorefinery & Borregaard \\
\hline SPAIN & Montmelo Succinic Acid & Succinity \\
\hline \multirow[t]{2}{*}{ SWEDEN } & Domsjö Pulp Mill & Aditya Birla Group \\
\hline & Piteå Tall-Oil Biorefinery & SunPine \\
\hline \multirow[t]{3}{*}{ UNITED KINGDOM } & Wissington Factory & British Sugar \\
\hline & Manchester Biorefinery & Cargill \\
\hline & Ensus Wheat Biorefinery & Ensus \\
\hline
\end{tabular}

Source: based on [20].

Table 4 Summary of potential develop of biorefineries in Europe

\begin{tabular}{lccc}
\hline Country & $\begin{array}{c}\text { No. of straw biorefineries from } \\
\text { indigenous feedstock }\end{array}$ & $\begin{array}{c}\text { No. of wood biorefinieries from } \\
\text { indigenous feedstock }\end{array}$ & $\begin{array}{c}\text { Total no. of biorefineries based } \\
\text { on indigenous feedstosk }\end{array}$ \\
Germany & 5 & 1 & 6 \\
Netherland & 0 & 0 & 0 \\
Poland & 0 & 3 & 3 \\
Spain & 3 & 2 & 5 \\
United Kingdom & 9 & 1 & 10 \\
Total: & 17 & 7 & 24 \\
& & & \\
\hline
\end{tabular}

Source: based on [18].

The biorefineries included in the list are identified as advanced because fulfill one or more of the following criteria: use of sustainable feedstocks, application of advanced biorefining processes, and high level of integration.

How many biorefineries can be supported in Europe depends on the availability of feedstock, land and investment capital. Thornley at al. [18] quantify the potential tra- de, employment and land impacts of economically viable European biorefinery options based on indigenous straw and wood feedstocks. The analysis presented by Thornley at al. [18] provide that there is scope for the development of around 24 biorefinery facilities at an economically viable scale in these 5 member states, as summarized in Table 4. 


\section{CONCLUSIONS}

The use of biomass as raw materials for bioenergy and biochemical production is encouraged by a reduction of fossil $\mathrm{CO}_{2}$ emissions, the need for a secure energy supply, and a revitalization of rural areas. Biomass energy and material recovery is maximized if a biorefinery approach is considered, where many technological processes are jointly applied to different kinds of biomass feedstock for producing a wide range of bioproducts. A lot of biorefinery pathways, from feedstock to products, can then be established, according to the different types of feedstock, conversion technologies and products. A key driver for the development and implementation of biorefineries is the growth in demand for energy, fuels, and chemicals. Accordingly, the aim of research is in developing new technologies and creating novel processes, products, and capabilities to ensure the growth is sustainable from economic, environmental and social perspectives. Further research and technology adoption will indicate which new products and processes contribute to more sustainable performances compared to conventional fossil based systems. When developing chemistry for future biorefineries, it is important that the methods and techniques used minimize impact to the environment and the final products are truly green and sustainable. The use of sustainable feedstock is not enough to ensure a prosperous future for later generation; protection of the environment using greener methodologies is also required.

The article is the result of the registered work with symbol 13/030/BK_16/0024 entitled

"Production engineering methods and tools

for development of smart specializations"

carried out in the Institute of the Production

Engineering, Department of Organization

and Management at Silesian University of Technology.

\section{REFERENCES}

[1] T. Berntsson et al. Swedish Pulp Mill Biorefineries - A vision of future possibilities, Swedish Energy Agency, 2006, pp. 1-30.

[2] T. Bludowsky and D.W. Agar. „Thermally integrated bio-syngas-production for biorefineries", in Chemical Engineering Research Design, vol. 87(9), August 2009, pp. 1328-1339.

[3] J.J. Bozell and G.R. Petersen. „Technology development for the production of biobased products from biorefinery carbohydrates-the US department of Energy's "Top 10" revisited", in Green Chemistry, vol. 12 (4), July 2010, pp. 539-554.

[4] F. Cherubini et al. "Toward a common classification approach for biorefinery systems", in Biofuels, Bioproducts and Biorefining, vol. 3(5), April 2009, pp. 534-546.

[5] F. Cherubini. „The biorefinery concept: using biomass instead of oil for producing energy and chemicals", in Energy Convers Managements, vol. 51(7), September 2010, pp. 1412-1421.
[6] E. de Jong, R. van Ree, I.K. Kwant. „Biorefineries: Adding Value to the Sustainable Utilisation of Biomass", in IEA Bioenergy, vol. 1, February 2009, pp. 1-16.

[7] F. Fava et al. „Biowaste biorefinery in Europe: opportunities and research \& development needs", in New Biotechnolology, vol. 32(1), September 2015, pp. 100108.

[8] S. Fernando, S. Adhikari, C. Chandrapal and N. Murali. „Biorefineries: current status, challenges, and future direction", in Energy Fuel, vol. 20 (4), June 2006, pp. 1727-1737.

[9] IEA Bioenergy Task 42. Biorefinery: processes for converting biomass into energy and chemical products, 2007. http://www.ieabioenergy.com/wp-content/ uploads/2013/10/Task-42-Booklet.pdf

[10] B. Kamm and M. Kamm. "Principles of biorefineries”, in Applied Microbiology and Biotechnology, vol. 64(2), April 2004, pp. 137-145.

[11] B. Kamm, P.R. Gruber and M. Kamm. Biorefineries industrial processes and products: Status quo and future directions, Weinheim: Wiley VCH, 2006.

[12] K. Menrad, A. Klein and S. Kurka. „Interest of industrial actors in biorefinery concepts in Europe", in Biofuels, Bioproducts and Biorefining, vol. 3(3), May/June 2009, pp. 384-394.

[13] A.R.C. Morais and R. Bogel-Lukasik. „Green chemistry and the biorefinery concept", in Sustainable Chemical Processes, vol. 1, September 2013, pp.18-24.

[14] S. Octave and D. Thomas. „Biorefinery: Toward an industrial metabolism", in Biochimie, vol. 91(6), February 2009, pp. 659-664.

[15] L.A. Pfaltzgraff and J.K. Clark. „Green chemistry, biorefineries and second generation strategies for re-use of waste: an overview", in Advances in Biorefineries, $\mathrm{K}$. Waldron, Cambridge: Woodhead Publishing Limited, 2014, pp. 3-33.

[16] G. Płaza, D. Wandzich and Z. Żurakowski. „Biobased economy - the future of the industry", in Zarzqdzanie Innowacjami w Produkcji i Usługach, J. Kaźmierczak and J. Bartnicka, Opole: Oficyna Wydawnicza Polskiego Towarzystwa Zarządzania Produkcją, 2014, pp. 284294.

[17] E.M. Shahid and Y. Jamal. „Production of biodiesel: a technical review”, in Renewable and Sustainable Energy Reviews, vol. 15(9), December 2011, pp. 47324745.

[18] P. Thornley, K. Chong and T. Bridgwater. „European biorefineries: Implications for land, trade and employment", in Environmental Science and Policy, vol. 37, March 2014, pp. 255-265.

[19] K.W. Waldron. Advances in Biorefineries, Biomass and Waste Supply Chain Exploitation, Cambridge: Woodhead Publishing Limited, 2014.

[20] R. van Ree and B. Annevelink (2007). Status report biorefinery [Online]. Available: http:// www.biorefinery.nl/fileadmin/biorefinery/docs/

dr hab. Grażyna A. Płaza, mgr inż. Dorota Wandzich

Silesian University of Technology, Faculty of Organization and Management

Institute of Production Engineering,

26 Roosevelt street, 41-800 Zabrze, POLAND

e-mail: gplaza@polsl.pl, dorota.wandzich@polsl.pl 